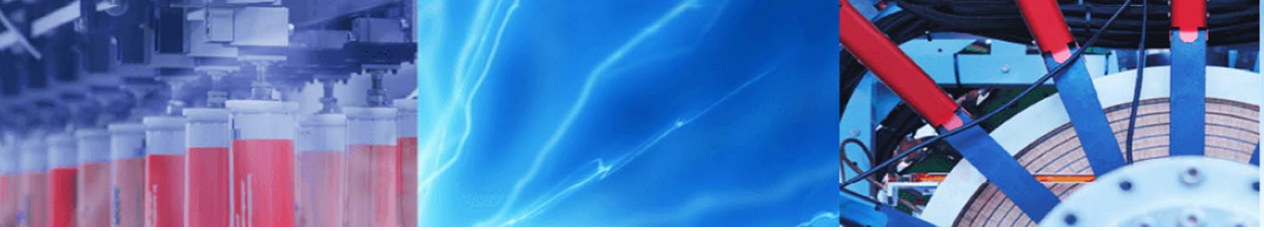

Short Communication

\title{
Big data challenges in overcoming China's water and air pollution: relevant data and indicators
}

\author{
Bo Zhang ${ }^{1} \cdot$ Robert M. Hughes ${ }^{2,3}$ (D) $\cdot$ Wayne S. Davis ${ }^{4} \cdot$ Cong Cao $^{5}$
}

Received: 26 November 2020 / Accepted: 25 February 2021 / Published online: 18 March 2021

(C) The Author(s) 2021 OPEN

\begin{abstract}
Big data are potentially useful for environmental management planning and actions that can be directed toward pollution control. China is using big data approaches to help reduce its current levels of pollution. However, also needed are better environmental indicators, measurement technologies, data management and reporting, and adaptive management and enforcement. Based on continental-extent monitoring and assessment programs in Europe and the USA, we recommend three major programmatic changes for China. (1) Establish long-term systemic environmental and human health objectives and indicators. (2) Adopt national standard methods for survey designs, sampling and analytical protocols, statistical analyses, and collaborative sampling programs. (3) Provide a transparent process for reporting and correcting data errors.
\end{abstract}

Keywords Indicators · Monitoring · Assessment · Data quality · Pollution management

\section{Introduction}

Recently, China has made considerable progress towards ecological and environmental protection through use of big data sets and analytics, which are increasingly being used by China's Ministry of Ecology and Environment (MEE). The MEE is currently gathering ecological and environmental information into one map via a virtual set of map overlays [54]. Key aims include centralizing data management, promoting system integration, maximizing data transparency, and improving standards and data security. Most USA federal agencies responsible for environmental protection are also using big data sets and analytics in their work (e.g., [29, 89]).

There are 5 key challenges to China's big data initiative: indicators, monitoring and assessment, data quality, data transparency, and rigorous adaptive management. If China can meet those challenges, it can fill substantial ecological research and management gaps by markedly increasing the extent and rigor of ecological information and pollution mitigation that is currently lacking in Asia [18]. Therefore, our goal in this paper is to provide specific examples of interdisciplinary and transdisciplinary big data programs that have been successfully implemented elsewhere.

\subsection{Quantitative indicators}

A suite of relevant, quantitative and cost-effective indicators is needed for tracking progress toward meeting clearly stated goals and objectives (Fig. 1; [34]). As shown in the figure, indicators begin with objectives or goals. For example, the goal of the USA Clean Air Act is to enhance "the quality of the Nation's air resources so as to promote the public health and welfare" [72]. The objective of the USA Clean Water Act is to restore "the chemical, physical,

\footnotetext{
$\triangle$ Robert M. Hughes, hughes.bob@amnisopes.com | ${ }^{1}$ Information Center, Ministry of Ecology and Environment, Beijing, China. ${ }^{2}$ Amnis Opes Institute, Corvallis, OR, USA. ${ }^{3}$ Department of Fisheries and Wildlife, Oregon State University, Corvallis, OR, USA. ${ }^{4}$ USEPA (Retired), Washington, DC, USA. ${ }^{5}$ University of Nottingham, Ningbo, China.
} 


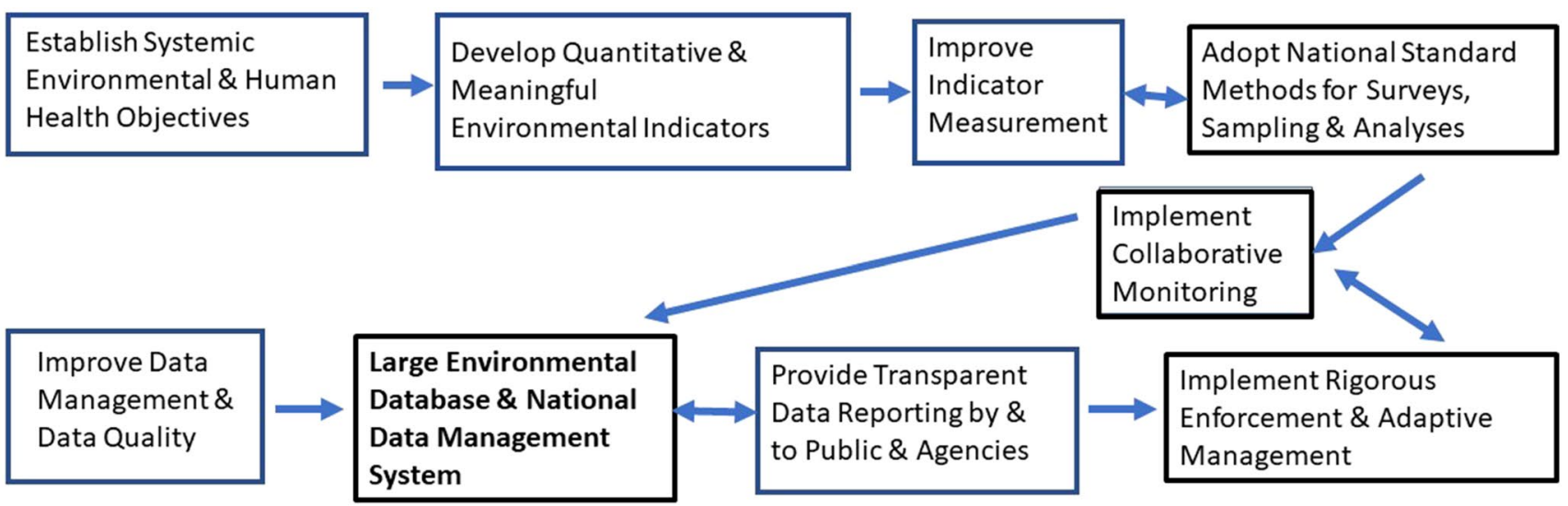

Fig. 1 Although implementing a big data program is a goal for China, additional improvements are needed to ensure that the public is clearly informed and that environmental monitoring and enforcement are rigorously implemented, as indicated in the critical steps above

and biological integrity of the nation's waters" [73]. Subsequently, the U.S. Environmental Protection Agency (USEPA) developed a hierarchy of administrative and environmental indicators represented by six levels (Fig. 2; [74]). Levels 1 and 2 are administrative measures to be linked to improvements in Level 5 and 6 indicators that are related to human and ecological health.

For example, USEPA's Level 5 and 6 indicators for surface waters include water quality, physical habitat structure, human health and biological assemblage indicators
(Table 1). All those indicators were developed and tested in regional pilot studies before being implemented nationwide. Before being deemed acceptable, each biotic indicator was evaluated for its range of variation, sensitivity to anthropogenic disturbance, sampling error or reproducibility, redundancy with other candidate indicators and then adjusted for natural variability if needed $[35,45$, $51,53,61,71,93]$. The choices of water quality indicators were based on sampling ease and cost, shipping restrictions, widespread use by state and federal water quality

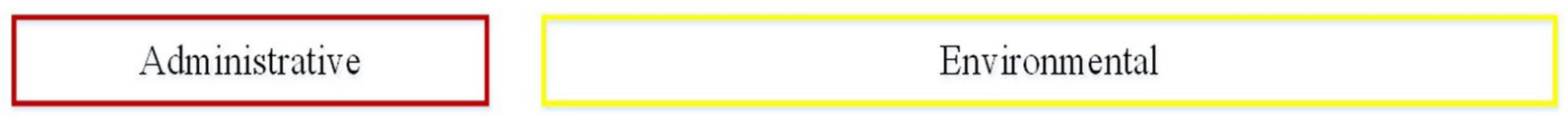

\begin{tabular}{l}
\hline $\begin{array}{c}\text { Level } 1 \\
\text { Actions by EPA, } \\
\text { state and other } \\
\text { regulatory } \\
\text { agencies }\end{array}$ \\
\hline Residential Lead \\
Paint Reduction Act \\
Lead Renovation, \\
Repair and Painting \\
Program Rule \\
Clean Air Act \\
Primary Lead \\
NAAQS \\
Safe Drinking Water \\
Act: Lead and \\
Copper Rule
\end{tabular}

- Lead removed from gasoline, paint, glazes

- Restrictions on smelters, other sources, cleanup efforts, lead paint hazard abatement and control

- Monitoring, emissions standards, and testing

- Establishment of NAAQS baselines

- Testing and regulation of drinking water supplies and distributions

systems

\section{Level 2}

Actions by regulated community

\section{Environmental}

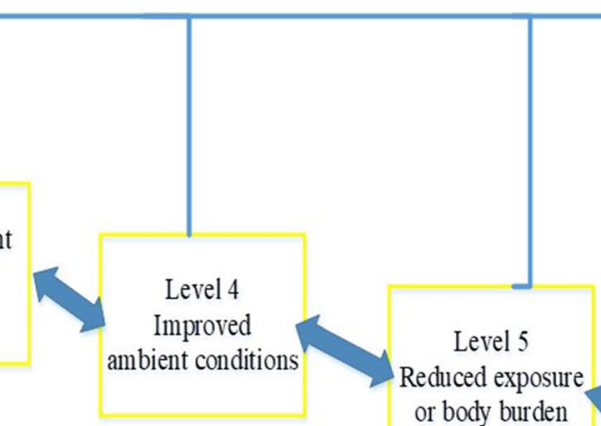

- NHANES

- State-level monitoring

- HUD and other evaluation and follow programs

- Community actions
- Effects on neural devel opment (IQ, behavior, special education), other physiologic systems

Fig. 2 Administrative and environmental indicators: levels one through six 
Table 1 Physical, chemical, and biological indicators of the USEPA national rivers and streams assessment, and the percent of waters in good and poor condition nationally. China lacks national monitoring of any of the listed indicators-except for total P \& total N (from USEPA [86])

\begin{tabular}{ll}
\hline Class & Indicators \\
\hline Biotic condition & Fish assemblage multimetric index $26 \%$ good; $37 \%$ poor \\
& Macroinvertebrate assemblage multimetric index $30 \%$ \\
& good; $44 \%$ poor \\
Water quality & Total phosphorus $18 \%$ good; $58 \%$ poor \\
& Total nitrogen $32 \%$ good; $43 \%$ poor \\
& Salinity $86 \%$ good; $4 \%$ poor \\
& Acid neutralizing capacity $98 \%$ good; $1 \%$ poor \\
& Excess fine sediments $52 \%$ good; $22 \%$ poor \\
& Fish habitat condition $64 \%$ good; $14 \%$ poor \\
Physical habitat structure & Riparian vegetation cover $58 \%$ good; $24 \%$ poor \\
& Anthropogenic riparian disturbance $29 \%$ good; $23 \%$ poor \\
& River fish tissue Hg $24 \%$ poor \\
Human health & Urban river fish tissue PFOs $3 \%$ poor \\
& Urban river fish tissue PCBs $40 \%$ poor \\
\hline
\end{tabular}

agencies, and responsiveness to a wide range of anthropogenic stressors and pressures $[27,34,93]$. Physical habitat condition indicators were selected based on sampling ease, equipment cost and responsiveness to a wide range of anthropogenic stressors and pressures [5, 34, 41-43, 63]. Selection of human health indicators were based largely on their frequency of occurrence and known toxicities [58, 59]. These fish consumption indicators are used by USEPA to evaluate and reduce exposure to harmful water pollutants (e.g., $[69,91])$. All the indicators listed in Table 1 are sampled by field crews using standard methods $[34,57$, $76,78,79]$ at approximately 1000 sites every 5 years. Those assemblage sampling methods are based on rigorous sampling effort studies (e.g., [6, 33, 48, 62]). The sites are selected by use of a dispersed probability design to ensure statistical representativeness, minimize site proximity and ensure rigorous status and trend assessments $[56,70]$.

USEPA's Level 5 and 6 air quality indicators include several of those monitored in China (Table 2), plus many additional toxic metals and organics as well as an air quality index based on 7 widespread contaminants (ground-level $\mathrm{O}_{3}, 2.5 \mu$ and $10 \mu$ particulates, $\mathrm{Pb}, \mathrm{CO}, \mathrm{SO}_{\mathrm{x}^{\prime}} \mathrm{NO}_{\mathrm{x}}$ ). Those indicators were selected because of their known correlations with the incidence of respiratory, cardiac and cancerous diseases [88]. They are monitored at approximately 3900 stations. Ambient air quality monitoring for toxic and non-toxic, or criteria, pollutants is primarily the responsibility of State agencies in the USA. EPA's Reports on the Environment (ROEs) are updated online reports available to the public [80], which include human exposure, health, and other indicators linked with ambient air indicators to reduce exposure to harmful air pollutants.

USEPA's water monitoring and regulation programs have two key limitations. Results have indicated that key anthropogenic pressures are largely related to minimally
Table 2 Key air pollutants monitored nationally and by source in China and the USA [38, 84, 85, 87]. Criteria successes are based on 90th percentiles of USA averages for ambient concentrations

\begin{tabular}{|c|c|}
\hline China & USA \\
\hline Total $\mathrm{SO}_{2}$ emissions & $\begin{array}{l}\text { Total anthropogenic } \mathrm{SO}_{2} \text { emissions } \\
\text { Met criteria since } 2002\end{array}$ \\
\hline Total $\mathrm{NO}_{2}$ emissions & $\begin{array}{l}\text { Total } \mathrm{NO}_{2} \text { emissions } \\
\text { Met criteria since } 2006\end{array}$ \\
\hline Total $\mathrm{NO}_{\mathrm{x}}$ emissions & $\begin{array}{l}\text { Total anthropogenic } \mathrm{NO}_{\mathrm{x}} \text { emissions } \\
\text { Met criteria since } 1980\end{array}$ \\
\hline Total $\mathrm{O}_{3}$ emissions & $\begin{array}{l}\text { Total anthropogenic } \mathrm{O}_{3} \text { emissions } \\
\text { Met criteria since } 2013\end{array}$ \\
\hline Total CO emissions & $\begin{array}{l}\text { Total anthropogenic CO emissions } \\
\text { Met criteria since } 1992\end{array}$ \\
\hline Total PM2.5 emissions & $\begin{array}{l}\text { Total anthropogenic PM2.5 emissions } \\
\text { Met criteria since } 2010\end{array}$ \\
\hline Total PM10 emissions & $\begin{array}{l}\text { Total anthropogenic PM10 emissions } \\
\text { Met criteria since } 1991\end{array}$ \\
\hline- & Total anthropogenic As emissions \\
\hline- & Total anthropogenic $\mathrm{Cd}$ emissions \\
\hline- & Total anthropogenic Cr emissions \\
\hline- & $\begin{array}{l}\text { Total anthropogenic Hg emissions } \\
\text { Met criteria since } 2015\end{array}$ \\
\hline- & $\begin{array}{l}\text { Total anthropogenic Pb emissions } \\
\text { Met criteria since } 2006\end{array}$ \\
\hline- & Total air toxic (187 pollutants) emissions \\
\hline - & Air Quality Index \\
\hline
\end{tabular}

regulated diffuse pollution $[18,40,46]$ compared with point source pollution, which has been widely curtailed. That pollution originates from agriculture $[9,30,44,75]$, livestock grazing $[1,19]$, mining $[11,37,95]$, flow regime alteration $[36,60]$ and non-native invasive species $[36,49]$. Furthermore, such pressures are frequently co-occurring both in the USA $[4,7]$ and Europe [66]. 
Regarding USA air pollution monitoring and regulation, there are 5 shortcomings. A growing concern is USEPA's failure to maintain its automated air monitoring stations [52]. Also, criteria air pollutants are sampled non-randomly near suspected sources, the data sources and modeling methods vary, and they are presented at such a granular level as to hinder statistically rigorous national statements.

The European Union (EU) approved its Water Framework Directive in 2000, with a goal of good water quality by protecting all types of water bodies, restoring ecosystems, reducing pollution, and guaranteeing sustainable water usage [16]. Good ecosystem condition is defined by use of fish, macroinvertebrate, algae, and macrophyte assemblage indicators (e.g., [25]) together with hydromorphology and water quality indicators. The EU 2013 Clean Air Protection Programme is focused on reducing air pollution, especially in cities [15], setting stricter national emission ceilings for six major pollutants, and reducing pollution from medium-sized pollution generators. Current ambient air criteria cover 12 major pollutants with monitoring periods from $1 \mathrm{~h}$ to 1 year.

The Chinese objectives neglect information about the extent to which pollution damages the environment or human health. China measures administrative and environmental indicators involving Level 1-4 indicators such as the percentages of surface waters and airsheds meeting, or not meeting, acceptable ranges of key chemical constituents. Although increases in asthma and other chronic respiratory diseases and premature mortality occur throughout China from ambient air pollution [17, 24], Level 5 and 6 indicators are missing for quantitatively measuring the effects of air and water quality on human health and biota.

\subsection{Monitoring and assessment}

China has implemented a network of ambient air quality monitors providing data that MEE and the provincial and local environmental protection bureaus (EPBs) can use to assess progress toward meeting established goals. However, many cases of monitoring system and data manipulation by local government officials have been reported, and several key air pollutants are still not monitored ([22, 98], Table 2).

Unlike water body monitoring in China, the USEPA implemented a National Aquatic Resources Survey (NARS) in 2000 based on a probabilistic design, standard sampling methods and indicators, and collaborative sampling by the states and government contractors. NARS provides statistically valid assessment of the ecological status and the relative importance of various stressors to all USA surface waters $[77,81-83,86]$. China has no similar national program.
Key results from the USEPA's NARS indicate that 3-40\% of the sampled population of rivers contain fish tissue levels of mercury, polychlorinated biphenyls or perfluorooctanesulfunic acid that warrant fish consumption warnings (Table 1, [86]). Regarding physical habitat structure, $14-24 \%$ of surface waters are in poor condition for fish habitat condition, excess fine sediments, riparian disturbance or riparian vegetation condition. Nutrient levels indicate that $43-58 \%$ of stream length is in poor condition. Based on the assemblage condition of fish and macroinvertebrates $37 \%$ and $44 \%$ of stream and river length is in poor condition (Table 1; [86]).

EPA's Report on the Environment [85] indicated that each of the criteria air pollutants has decreased over time and have met national standards for 5-20 years (Table 2). Although the National Air Toxics Assessment (NATA) reports are only published about every 4 years, there is a source of consistent and comparable data regarding air toxics that is part of the annual Toxics Release Inventory, a self-reporting system of the most significant industrial sources of pollution. A similar exposure modeling routine as used in NATA, called Risk Screening Environmental Indicators (RSEI), is employed to estimate ambient concentrations of air toxics with the goal of establishing the relative human health risks throughout the USA. RSEI uses a big data analytics application, called Qlik Sense, to display national data with the ability to sift the results down to a single facility among the over 20,000 facilities in the database [87]. The RSEI national relative risk trend decreased since 2007 and has remained relatively stable since 2016 . However, the RSEl model results indicate continued risks to economically disadvantaged populations $[10,97]$, which also indicates the value of publicly available pollution data.

The EU member states use ad hoc approaches to select sites, but many states employ standard field methods and data analyses and measure multiple assemblages at least annually at each site. Those differences in methods and data interpretation complicate some EU-wide assessments [26] because observed differences in assemblages are confounded by differences in field sampling and data processing protocols. But see $[64,65]$ for examples obtained from standard sampling methods. Schinegger et al. [66] reported that $73 \%$ of 3105 study sites were impaired; $43 \%$ of all sites were impaired by multiple stressors.

Citizen-science and consumer-based environmental monitoring equipment has made it easier for citizens to participate in data collection and scientific research [12]. Such citizens have measured water quality, assessed physical habitat conditions, and evaluated fish and macroinvertebrate status through use of standard protocols (e.g., [20, 55]. Citizen scientists are typically more invested in environmental improvement and protection than the average citizen $[20,21]$. 
It would be cost-effective for China to adopt national standard methods for survey designs, sampling and analytical protocols, statistical analyses, collaborative sampling by provincial governments and academics, open data reporting, and peer-review publications. Doing so could engage an enormous number of scientific collaborators as well as markedly increase database sizes and quality, thereby improving data quality and usefulness. For example, in Oregon (USA), water body monitoring and assessment data from eight different institutions were easily synthesized because all used a standard survey design, standard methods, and the same environmental and biological indicators [55]. Multiple Brazilian universities employed the same NARS survey design, standard sampling methods, and indicators for regionally assessing Atlantic Forest [39] Cerrado [8,68] and Amazônia [3, 47] streams. Jimenez-Valencia et al. [39] determined that $62 \%$ of basin stream length was in poor condition based on macroinvertebrate assemblage condition,the risk of poor condition was four-fold greater in catchments with degraded forest. Silva et al. [67] estimated that $27 \%$ of the stream length in four hydrologic units had poor macroinvertebrate condition. Those poor conditions were twice as likely at high levels of turbidity and fine sediments [68]. Leitão et al. [47] reported that local and catchment deforestation decreased instream large wood, which decreased fish species richness and functional originality. Such assessments would have been inconceivable by single institutions working alone and using differing protocols.

\subsection{Data quality}

Problems exist in China with data availability, interruptions in time series, inconsistencies between different sources reporting similar energy and air quality statistics, and a lack of data transparency [31, 38]. China's pollution emissions data have not been standardized, leading to uncertainty in results and preventing EPBs from fully assessing actual discharge conditions [90]. In comparison, EPA and EU data quality from monitoring and assessment programs allow continental-extent assessments and scientific interpretations of key causal factors for all USA (e.g., $[77,81-83,86])$ and many EU $[23,65]$ surface waters. EU indicators differ somewhat among nations, but they have been intercalibrated for making Europe-wide assessments $[23,65]$. Both standard methods and a rigorous statistical probability design allow inference to all conterminous USA surface waters with known confidence intervals [77, 81-83, 86].

We offer five recommendations for improving China's data quality based on USEPA [84]. (1) All data must contain metadata for interpreting and reproducing results to ensure that all potential users can analyze the data. (2) A single centralized data exchange should be implemented, in which the different participants maintain their own databases but seamlessly exchange a common set of necessary data for tracking national, provincial, and local environmental progress. (3) Require that enterprises, MEE, and EPBs electronically report quantitative pollution discharge data to the central data exchange. (4) Implement effective supervision and auditing through periodic, unscheduled inspections of enterprises, MEE, and EPBs to verify their reporting to correct data errors immediately. (5) Impose stiff penalties and public notice for individuals and entities that deliberately or accidentally falsify data and hold governmental officials accountable for any environmental data fraud cases under their jurisdiction.

\subsection{Data transparency}

The transparency of China's environmental data remains problematic [14]. Data are scattered across various platforms and agency websites. The disclosure of information from EIAs is insufficient to support meaningful and robust public engagement. Conversely, in the USA, the NARS data are available for non-federal users to download, analyze, interpret, and publish as they wish, which greatly amplifies the usefulness and applications of the data (e.g., [9, $13,28]$ ). EPA electronic reporting and disclosure of large databases includes water pollution discharge monitoring reports and industry self-reported toxics release inventories. USEPA's [75] information quality guidelines provide a process for the public to access and officially report errors they find in the data from almost 22,000 facilities and to have them corrected.

\subsection{Adaptive management}

We believe that a key towards continued improvement requires government employees to view themselves as ecosystem (nature) trustees always keeping in mind the goals and objectives of the empowering legislation [94]. Citizens should be viewed as the trust beneficiaries, nature should be viewed as quantifiably valued assets of the trust, and government decision-making should be based on the fiduciary responsibility of the trustee. Polluters should be viewed as nature and human despoilers, their payments to government employees should be viewed as illegal bribes, and government employees who fail to meet their fiduciary responsibilities should be treated as criminal offenders $[92,94]$.

Resource management should be based on a rigorous adaptive management paradigm [50,96]. Rigorous adaptive management and plans are based on: (1) specifying clear sets of general goals and explicit objectives; (2) explicitly stating actions that will and will not be taken 
when pre-identified trigger points occur; (3) explicitly identifying what is and is not known about the problems and their resolution; (4) clearly explaining expected conditions; (5) designing and implementing monitoring programs for learning about the above uncertainties; and (5) using the monitoring information to revise predictive models and management actions.

\section{Conclusions}

Common concerns to pollution control globally include government inaction, resistance of industries and citizens toward environmental protection, false arguments of jobs versus the environment and human health, externalities and lag effects, and resistance toward long-term and large-extent strategic thinking. But those also are the drivers for better analysis of big data. China can draw on international and historical experience in tackling its environmental challenges and improving its big data. The implementation of such an initiative goes beyond the technology itself. It requires the efforts of the entire society, the resolve of political leaders, and an institutional framework to fully understand the indicators developed from the data and how the country will most effectively use the data. The successes or failures that China exhibits in resolving its air and water pollution problems will serve as explicit indicators of its ability to solve environmental problems affecting human health and quality of life nationally and globally.

Acknowledgements The views expressed in this paper are those of the authors only and do not reflect the views of China's Ministry of Ecology and Environment (MEE), the United States Government, or the United States Environmental Protection Agency (USEPA). The authors did not do this work in any governmental or private capacity and this work is not a product of the MEE, the USEPA, or Amnis Opes Institute.

Funding We declare no financial or personal relationships with other people or organizations that could inappropriately influence this manuscript or our work in general, and we received no financial support from the institutions with which we are affiliated for the literature review or the preparation of the article.

\section{Declarations}

Conflict of interest Author Hughes was employed by the company Amnis Opes Institute. The remaining authors declare that the research was conducted in the absence of any commercial or financial relationships that could be construed as a potential conflict of interest.

Open Access This article is licensed under a Creative Commons Attribution 4.0 International License, which permits use, sharing, adaptation, distribution and reproduction in any medium or format, as long as you give appropriate credit to the original author(s) and the source, provide a link to the Creative Commons licence, and indicate if changes were made. The images or other third party material in this article are included in the article's Creative Commons licence, unless indicated otherwise in a credit line to the material. If material is not included in the article's Creative Commons licence and your intended use is not permitted by statutory regulation or exceeds the permitted use, you will need to obtain permission directly from the copyright holder. To view a copy of this licence, visit http://creativecommons .org/licenses/by/4.0/.

\section{References}

1. Beschta RL, Donahue DL, DellaSala DA, Rhodes JJ, Karr JR, O'Brien MH, Fleischner TL, Williams CD (2013) Adapting to climate change on western public lands: addressing the ecological effects of domestic, wild, and feral ungulates. Environ Manag 51:474-491

2. Bonney R, Phillips T, Ballard H, Enck J (2016) Can citizen science enhance public understanding of science? Public understand. Sci 25:2-16

3. Brito JG, Roque FO, Martins RT, Hamada N, Nessimian JL, Oliveira VC, Hughes RM, de Paula FR, Ferraz S (2020) Small forest losses degrade stream macroinvertebrate assemblages in the eastern Brazilian Amazon. Biol Cons 241:108263

4. Brown LR, Cuffney TF, Coles JF, Fitzpatrick F, McMahon G, Steuer J, Bell AH, May JT (2009) Urban streams across the USA: lessons learned from studies in 9 metropolitan areas. J N Am Benthol Soc 28:1051-1069

5. Bryce SA, Lomnicky GA, Kaufmann PR (2010) Protecting sediment-sensitive aquatic species in mountain streams through the application of biologically based streambed sediment criteria. J N Am Benthol Soc 29:657-672

6. Cao Y, Larsen DP, Hughes RM, Angermeier PL, Patton TP (2002) Sampling effort affects multivariate comparisons of stream communities. J N Am Benthol Soc 21:701-714

7. Carlisle DM, Hawkins CP (2008) Land use and the structure of western US stream invertebrate assemblages: predictive models and ecological traits. J N Am Benthol Soc 27:986-999

8. Carvalho DR, Leal CG, Junqueira NT, Castro MA, Fagundes DC, Alves CBM, Hughes RM, Pompeu PS (2017) A fish-based multimetric index for Brazilian savanna streams. Ecol Indic 77:386-396

9. Chen KD, Olden JD (2020) Threshold responses of riverine fish communities to land use conversion across regions of the world. Glob Chang Biol 26:4952-4965

10. Collins M, Munoz I, JaJa J (2016) Linking "toxic outliers" to environmental justice communities. Environ Res Lett 11:015004

11. Daniel DM, Infante DM, Hughes RM, Esselman PC, Tsang Y-P, Wieferich D, Herreman K, Cooper AR, Wang L, Taylor WW (2014) Characterizing coal and mineral mines as a regional source of stress to stream fish assemblages. Ecol Indi 50:50-61

12. Danielsen $F$, Burgess ND, Balmford $A$, Donald PF, Funder $M$, Jones JP, Alviola P, Balete DS, Blomley T, Brashares J, Child B, Enghoff M, Fjeldsá J, Holt S, Hübertz $H$, Jensen AE, Jensen PM, Massao J, Mendoza MM, Ngaga Y, Poulsen MK, Rueda R, Sam M, Skielboe T, Stuart-Hill G, Topp-Jørgensen E, Yonten D (2009) Local participation innatural resource monitoring: a characterization of approaches. Conserv Biol 23:31-42

13. Esselman PC, Infante DM, Wang L, Cooper AR, Wieferich D, Tsang Y-P, Thornbrugh DJ, Taylor WW (2013) Regional fish community indicators of landscape disturbance to catchments of the conterminous United States. Ecol Indi 26:163-173 
14. EPI (Environmental Performance Index) (2018) Results. https ://epi.yale.edu/epi-results/2020/component/epi. Accessed March 2021

15. European Commission (2013) Environment: new policy package to clean up Europe's air. Available at: https://ec.europa.eu/ commission/presscorner/detail/en/IP_13_1274. Accessed March 2021

16. European Community (2017) Good-quality water in Europe (EU water directive). Available at: https://eur-lex.europ a.eu/legal-content/EN/TXT/HTML/?uri=LEGISSUM:I28002b. Accessed March 2021

17. Fang D, Wang QG, Li H, Yu Y, Lu Y, Qian X (2016) Mortality effects assessment of ambient PM 2.5 pollution in the 74 leading cities of China. Sci Total Environ 569:1545-1552

18. Feio MJ et al (2021) The state of science in assessing and rehabilitating the biological condition of the world's rivers. Water 13:371. https://doi.org/10.3390/w13030371

19. Fleischner TL (1994) Ecological costs of livestock grazing in western North America. Conserv Biol 8:629-644

20. França JS, Solar RS, Hughes RM, Callisto M (2019) Student monitoring of the ecological quality of neotropical urban streams. Ambio 48:867-878

21. Fraser E, Dougill A, Mabee W, Reed M, McAlpine P (2006) Bottom up and top down: analysis of participatory processes for sustainability indicator identification as a pathway to community empowerment and sustainable environmental management. J Environ Manag 78:114-127

22. Ghanem D, Zhang J (2014) 'Effortless perfection': do Chinese cities manipulate air pollution data? J Environ Econ Manag 68:203-225

23. Grizzetti B, Pistacchi A, Liquete $C$, Udias A, Bouraoui F, van de Bund W (2017) Human pressures and ecological status of European rivers. Sci Rep 7:205. https://doi.org/10.1038/s4159 8-017.00324-3

24. Guan WJ, Zheng XY, Chung KF, Zhong NS (2016) Impact of air pollution on the burden of chronic respiratory diseases in China: time for urgent action. Lancet 388:1939-1951

25. Hering D, Borja A, Carstensen J, Carvalho L, Elliott M, Feld CK, Heiskanen A-S, Johnson RJ, Moe J, Pont D, Solheim AL, van de Bund W (2010) The European water framework directive at the age of 10: a critical review of the achievements with recommendations for the future. Sci Total Environ 408:4007-4019

26. Hering D, Moog O, Sandin L, Verdonschot PFM (2004) Overview and application of the AQEM assessment system. Hydrobiol 516:1-20

27. Herlihy AT, Paulsen SG, Van Sickle J, Stoddard JL, Hawkins CP Yuan LL (2008) Striving for consistency in a national assessment: the challenges of applying a reference-condition approach at a continental scale. J N Am Benthol Soc 27:860-877

28. Herlihy AT, Sifneos JC, Hughes RM, Peck DV, Mitchell RM (2020) Relation of lotic fish and benthic macroinvertebrate condition indices to environmental factors across the conterminous USA. Ecol Indic 112:105958

29. Hill RA, Weber MH, Leibowitz SG, Olsen AR, Thornbrugh DJ (2016) The stream-catchment (StreamCat) dataset: a database of watershed metrics for the conterminous United States. J Am Water Resour Assoc 52:120-128

30. Hill RA, Fox EW, Leibowitz SG, Olsen AR, Thornbrugh DJ, Weber $\mathrm{MH}$ (2017) Predictive mapping of the biotic condition of conterminous U.S. rivers and streams. Ecol Appl 27:2397-2415

31. Hornby $L$ (2014) China admits widespread soil pollution in'state secret' report. The Financial Times. 18 April. http://www.ft.com/ cms/s/0/c250bd4c-c6b4-11e3-9839-00144feabdc0.html\#axzz4 MooWmpda
32. Hughes $B$ (2013) A call for better mining regulations. Fisheries 38:391-391

33. Hughes RM, Herlihy AT (2007) Electrofishing distance needed to estimate consistent IBI scores in raftable Oregon rivers. Trans Am Fish Soc 136:135-141

34. Hughes RM, Peck DV (2008) Acquiring data for large aquatic resource surveys: the art of compromise among science, logistics, and reality. J N Am Benthol Soc 27:837-859

35. Hughes RM, Howlin S, Kaufmann PR (2004) A biointegrity index for coldwater streams of western Oregon and Washington. Trans Am Fish Soc 133:1497-1515

36. Hughes RM, Rinne JN, Calamusso B (2005) Historical changes in large river fish assemblages of the Americas: a synthesis. In Rinne JN, Hughes RM, Calamusso B (eds.). Historical changes in large river fish assemblages of the Americas. Am Fish Soc Symp 45:603-612

37. Hughes RM, Amezcua F, Chambers DM, Daniel WM, Franks JS, Franzin W, MacDonald D, Merriam E, Neall G, Pompeu PS, Reynolds L, Woody CA (2016) AFS position paper and policy on mining and fossil fuel extraction. Fisheries 41:12-15

38. Hsu A, de Sherbinin A, Shi H (2012) Seeking truth from facts: the challenge of environmental indicator development in China. Environ Dev 3:39-51

39. Jimenez-Valencia J, Kaufmann PR, Sattamini A, Mugnai R, Baptista DF (2014) Assessing the ecological condition of streams in a southeastern Brazilian basin using a probabilistic monitoring design. Environ Monit Assess 186:4685-4695

40. Karr JR, Dudley DR (1981) Ecological perspective on water quality goals. Environ Manag 5:55-68

41. Kaufmann PR, Levine P, Robison EG, Seeliger C, Peck DV (1999) Quantifying physical habitat in wadeable streams. EPA/620/R-99/003. U.S. Environmental Protection Agency, Corvallis, Oregon

42. Kaufmann PR, Hughes RM (2006) Geomorphic and anthropogenic influences on fish and amphibians in Pacific Northwest coastal streams. In Hughes RM, L. Wang L, Seelbach PW (eds.). Landscape influences on stream habitat and biological assemblages. Am Fish Soc Symp 48:429-455

43. Kaufmann PR, Larsen DP, Faustini JM (2009) Bed stability and sedimentation associated with human disturbances in Pacific Northwest streams. J Am Water Resour Assoc 45:434-459

44. Kaufmann PR, Hughes RM, Paulsen SG, Peck DV, Seeliger $C$, Mitchell R (In Review) Quantitative assessment of stream and river physical habitat condition. Ecol Indic

45. Klemm DJ, Blocksom KA, Fulk FA, Herlihy AT, Hughes RM, Kaufmann PR, Peck DV, Stoddard JL, Thoeny WT, Griffith MB, Davis WS (2003) Development and evaluation of a macroinvertebrate biotic integrity index (MBII) for regionally assessing Mid-Atlantic Highlands streams. Environ Manag 31:656-669

46. Laitos JG, Ruckriegle $H$ (2013) The clean water act and the challenge of agricultural pollution. Vt Law Rev 37:1033-1070

47. Leitão RP, Zuanon J, Mouillot D, Leal CG, Hughes RM, Kaufmann PR, Villéger S, Pompeu PS, Kasper D, de Paula FR, Ferraz SFB, Gardner T (2018) Disentangling the pathways of land use impacts on the functional structure of fish assemblages in Amazon streams. Ecography 41:219-232

48. Li J, Herlihy A, Gerth W, Kaufmann PR, Gregory S, Urquhart S, Larsen DP (2001) Variability in stream macronvertebrates at multiple spatial scales. Freshw Biol 46:87-97

49. Lomnicky GA, Whittier TR, Hughes RM, Peck DV (2007) Distribution of nonnative aquatic vertebrates in western U.S. streams and rivers. N Am J Fish Manag 27:1082-1093

50. Maas-Hebner KG, Schreck CB, Hughes RM, Yeakley JA, Molina N (2016) Scientifically defensible fish conservation and recovery 
plans: addressing diffuse threats and developing rigorous adaptive management plans. Fisheries 41:276-285

51. McCormick FH, Hughes RM, Kaufmann PR, Herlihy AT, Peck DV (2001) Development of an index of biotic integrity for the MidAtlantic Highlands Region. Trans Am Fish Soc 130:857-877

52. McLaughlin T, Kearney L, Sanicola L (2020) U.S. air monitors routinely miss pollution-even refinery explosions. Reuters https ://www.reuters.com/article/usa-pollution-airmonitors-speci alreport/special-report-u-s-air-monitors-routinely-miss-pollu tion-even-refinery-explosions-idUSKBN28B4RT

53. Mebane CA, Maret TR, Hughes RM (2003) An index of biological integrity (IBI) for Pacific Northwest rivers. Trans Am Fish Soc 132:239-261

54. MEE (China Ministry of Ecology and Environment) (2018) MEE holds a ministerial executive meeting. http://english.mep.gov. cn/News_service/news_release/201804/t20180411_43427 5.shtml

55. Mulvey $M$, Leferink $R$, Borisenko $A$ (2009) Willamette basin rivers and streams assessment. DEQ 09-LAB-016. Oregon Department of Environmental Quality. Portland, Oregon. https://www.orego n.gov/deq/FilterDocs/WillametteBasinAssessment2009.pdf

56. Olsen AR, Peck DV (2008) Survey design and extent estimates for the wadeable streams assessment. J N Am Benthol Soc 27:822-836

57. Peck DV, Herlihy AT, Hill BH,. Hughes RM, Kaufmann PR, Klemm DJ, Lazorchak JM, McCormick FH, Peterson SA, Ringold PL, Magee T, Cappaert MR (2006) Environmental monitoring and assessment program-surface waters: western pilot study field operations manual for wadeable streams. EPA/620/R-06/003. U.S Environmental Protection Agency, Washington, DC

58. Peterson SA, Hughes RM, Herlihy AT, Motter KL, Robbins JM (2002) Regional evaluation of mercury contamination in Oregon freshwater fish. Environ Tox Chem 21:2157-2164

59. Peterson SA, Van Sickle J, Herlihy AT, Hughes RM (2007) Mercury concentration in fish from streams and rivers throughout the western United States. Environ Sci Tech 41:58-65

60. Poff NL, Olden JD, Merritt DM, Pepin DM (2007) Homogenization of regional river dynamics by dams and global biodiversity implications. Proc Nat Acad Sci USA 104:5732-5737

61. Pont $D$, Hughes RM, Whittier TR, Schmutz S (2009) A predictive index of biotic integrity model for aquatic-vertebrate assemblages of western U.S. streams. Trans Am Fish Soc 138:292-305

62. Reynolds L, Herlihy AT, Kaufmann PR, Gregory SV, Hughes RM (2003) Electrofishing effort requirements for assessing species richness and biotic integrity in western Oregon streams. N Am J Fish Manag 23:450-461

63. Roper BB, Buffington JM, Bennett S, Lanigan SH, Archer E, Downe ST, Faustini J, Hillman TW, Hubler S, Jones K, Jordan C, Kaufmann PR, Merritt G, Moyer C, Pleus A (2010) A comparison of the performance and comparability of protocols used by seven monitoring groups to measure stream habitat in the Pacific Northwest. N Am J Fish Manag 30:565-587

64. Schinegger R, Trautwein C, Melcher A, Schmutz S (2011) Multiple human pressures and their spatial patterns in European running waters. Water Environ J. https://doi.org/10.111 1/j.1747-6593.2011.00285.x

65. Schinegger R, Trautwein C, Schmutz S (2013) Pressure-specific and multiple pressure response of fish assemblages in European running waters. Limnologica 43:348-361

66. Schinegger R, Palt M, Segurado P, Schmutz S (2016) Untangling the effects of multiple human stressors and their impacts on fish assemblages in European running waters. Sci Total Environ 573:1079-1088

67. Silva DRO, Herlihy AT, Hughes RM, Callisto M (2017) An improved macroinvertebrate multimetric index for the assessment of wadeable streams in the neotropical savanna. Braz Ecol Indic 81:514-525

68. Silva D, Herlihy AT, Hughes RM, Macedo DR, Callisto M (2018) Assessing the extent and relative risk of aquatic stressors on stream macroinvertebrate assemblages in the neotropical savanna. Sci Total Environ 633:179-188

69. Stahl LS, Snyder BD, Olsen AR, Pitt JL (2009) Contaminants in fish tissue from US lakes and reservoirs: a national probabilistic study. Environ Monit Assess 150:3-19

70. Stevens DL, Olsen AR (2004) Spatially balanced sampling of natural resources. J Am Stat Assoc 99:262-278

71. Stoddard JL, Herlihy AT, Peck DV, Hughes RM, Whittier TR, Tarquinio $E$ (2008) A process for creating multi-metric indices for large-scale aquatic surveys. J N Am Benthol Soc 27:878-891

72. USA (United States) (1970) The clean air act. 42 U.S.C. 7401 et seq. https://www.gpo.gov/fdsys/pkg/USCODE-2010-title42/ html/USCODE-2010-title42-chap85.htm

73. USA (United States) (1972) Federal water pollution control act amendments of 1972. 33 U.S.C. 1251 et seq. https://www.epa. gov/sites/production/files/2017-08/documents/federal-water -pollution-control-act-508full.pdf

74. USEPA (U. S. Environmental Protection Agency) (1995) A conceptual framework to support development and use of environmental information in decision-making. EPA 239-R-95-012. Office of Policy, Planning, and Evaluation, Washington, DC

75. USEPA (U. S. Environmental Protection Agency) (2002) Guidelines for ensuring and maximizing the quality, objectivity, utility, and integrity of information disseminated by the environmental protection agency. EPA/260R-02-008. Office of Environmental Information, Washington, DC

76. USEPA (United States Environmental Protection Agency) (2009) National rivers and streams assessment: field operations manual. EPA 841/B-04/004, Office of Water and Office of Environmental Information, US Environmental Protection Agency, Washington, DC

77. USEPA (U. S. Environmental Protection Agency) (2012) National coastal condition report IV. EPA-842-R-10-003. Office of Research and Development/Office of Water. Washington, DC. http://www.epa.gov/nccr

78. USEPA (United States Environmental Protection Agency) (2013a) National Rivers and Streams Assessment 2013/14: field operations manual-wadeable. EPA 841/B-12/009b, Office of Water and Office of Environmental Information, US Environmental Protection Agency, Washington, DC

79. USEPA (United States Environmental Protection Agency) (2013b) National Rivers and Streams Assessment 2013/14: field operations manual-non-wadeable. EPA 841/B-12/009a, Office of Water and Office of Environmental Information, US Environmental Protection Agency, Washington, DC

80. USEPA (U. S. Environmental Protection Agency) (2014) EPA's report on the environment (ROE). USEPA, Washington, DC. https ://cfpub.epa.gov/roe/

81. USEPA (U. S. Environmental Protection Agency) (2016a) National wetland condition assessment: a collaborative survey of the Nation's wetlands. EPA-843-R-15-006. Office of Water/Office of Research and Development. Washington, DC. https://www.epa. gov/sites/production/files/2016-05/documents/nwca_2011_ public_report_20160510.pdf

82. USEPA (U. S. Environmental Protection Agency) (2016b) National rivers and streams assessment 2008-2009: a collaborative survey. EPA/841/R-16/007. Office of Water/Office of Research and Development. Washington, DC. http://www.epa.gov/nationalaquatic-resource-surveys/nrsa

83. USEPA (U. S. Environmental Protection Agency) (2016c), National lakes assessment 2012: a collaborative survey of lakes in the United States. EPA 841-R-16-113. Office of Water/Office of 
Research and Development. Washington, DC. https://nationalla kesassessment.epa.gov/

84. USEPA (U. S. Environmental Protection Agency) (2018) Toxics release inventory. https://www.epa.gov/TRI

85. USEPA (U. S. Environmental Protection Agency) (2019) EPA's report on the environment (ROE): outdoor air quality. https:// www.epa.gov/report-environment/outdoor-air-quality

86. USEPA (U. S. Environmental Protection Agency) (2020) National rivers and streams assessment 2013-2014: a collaborative survey. EPA 841-R-19-001. Office of Water/Office of Research and Development. Washington, DC. https://www.epa.gov/sites/ production/files/2020-12/documents/nrsa_2013-14_final_repor t_2020-12-17.pdf

87. USEPA (U. S. Environmental Protection Agency) (2021a) RSEIEasyRSE dashboard version 2.3.9. USEPA office of pollution prevention and toxic substances. RSEl results record year 2019. https://edap.epa.gov/public/extensions/EasyRSEI/EasyRSEl. html\#home

88. USEPA (United States Environmental Protection Agency) (2021b) Criteria air pollutants. https://www.epa.gov/criteria-air-pollu tants

89. Wang L, Infante D, Riseng C, Wehrly K (2016) Advancement of geospatial capability by NRiSD and GLAHF in enhancing aquatic ecosystem research and management. Geoinform Geostat $4(2): 1-5$

90. Wang X, Zhao XT, Lu Z, Wang JX, Zhou J, An HR, Yang WS, Zhao JS (2014) Research on environmental statistical data direct reporting and quality control for national key supervision enterprises. Environ Monit China 30(6):36-41 (in Chinese)

91. Wathen JB, Lazorchak JM, Olsen AR, Batt A (2015) A national statistical survey assessment of mercury concentrations in fillets of fish collected in the U.S. EPA national rivers and streams assessment of the continental USA. Chemosphere 122:52-61
92. Westra L (2016) Ecological integrity and global governance: science, ethics and the law. Routledge, New York

93. Whittier TR, Hughes RM, Stoddard JL, Lomnicky GA, Peck DV, Herlihy AT (2007) A structured approach to developing indices of biotic integrity: three examples from western USA streams and rivers. Trans Am Fish Soc 136:718-735

94. Wood MC (2014) Nature's trust: environmental law for a new ecological age. Cambridge University Press, New York

95. Woody CA, Hughes RM, Wagner EJ, Quinn TP, Roulsen LH, Martin LM, Griswold K (2010) The U.S. general mining law of 1872: change is overdue. Fisheries 35:321-331

96. Yoder CO, Rankin ET, Gordon VL, Hersha LE, Boucher CE (2019) Degradation and recovery of Scioto River (Ohio-USA) fish assemblages from pre-settlement to present-day conditions. In: Krueger C, Taylor W, Youn S-J (eds) From catastrophe to recovery: stories of fish management success. American Fisheries Society, Bethesda, Maryland, pp 233-265

97. Younes L, Shaw A, Petroni M (2019) Polluter's paradise: how we found new chemical plants are being built in south Louisiana's most polluted areas. ProPublica October 30. https://www.propu blica.org/article/how-we-found-new-chemical-plants-are-being -built-in-south-ouisianas-most-polluted-areas

98. Zhang X, Schreifels J (2011) Continuous emission monitoring systems at power plants in China: improving $\mathrm{SO}_{2}$ emission measurement. Energy Policy 39:7432-7438

Publisher's Note Springer Nature remains neutral with regard to jurisdictional claims in published maps and institutional affiliations. 